\title{
Studia
}

SYNCHRONICZNE I DIACHRONICZNE ASPEKTY BADAŃ POLSZCZYZNY

www.wnus.edu.pl/sj | DOI: 10.18276/sj.2016.15-17 | 251-254

BOGDAN WALCZAK

Akademia im. Jakuba z Paradyża

Gorzów Wielkopolski

\section{Joanna Kuć, Polszczyzna tukowskich aktów notarialnych z poczatku XIX wieku, Wydawnictwo Uniwersytetu Przyrodniczo-Humanistycznego w Siedlcach, Siedlce 2013, ss. 339}

Praca Joanny Kuć sytuuje się w obszarze historii języka polskiego, ściślej: w tym nurcie badań historycznojęzykowych, które mają za przedmiot dzieje różnych odmian stylowych polszczyzny - dotyczy bowiem wycinka dziejów polskiego języka prawniczego. Mój najogólniejszy sąd o pracy Joanny Kuć daje się streścić w następujących słowach: jest to bardzo wartościowa, przemyślana w każdym szczególe, doskonale skomponowana rozprawa, która zainteresuje zarówno historyka języka polskiego, jak i historyka prawa, a w dalszej kolejności także badacza kultury społecznej i materialnej ziemi łukowskiej na początku XIX wieku. W moim przekonaniu o wartości rozprawy stanowią przede wszystkim następujące jej elementy i aspekty:

1. Wybór tematu. Wiek XIX, mimo fundamentalnego opracowania Ireny Bajerowej (Polski język ogólny XIX wieku: stan i ewolucja, t. I-III, Katowice 1986-2000), wciąż jeszcze kryje w sferze języka wiele tajemnic, a w szczególności dotyczy to różnych odmian stylowych, socjo- i profesjolektalnych itd. (fundamentalna monografia Bajerowej ma za przedmiot opisu język literacki). Gdy chodzi o z wielu względów bardzo interesujący użytkowy gatunek wypowiedzi, jakim jest akt notarialny, dysponujemy, jak wiadomo, monograficznym opisem, autorstwa Anny Dunin-Dudkowskiej (Akt notarialny jako gatunek wypowiedzi, Lublin 2010), współczesnego aktu notarialnego, brak było natomiast większego, 
całościowego, monograficznie zakrojonego studium z dziejów aktu notarialnego jako gatunku. Tę lukę w literaturze naukowej wypełnia praca Joanny Kuć.

2. Precyzyjny, wyczerpujący opis łukowskich aktów notarialnych z perspektywy komunikologii, lingwistyki tekstu, teorii aktów mowy i zwłaszcza genologii lingwistycznej. Widać, że autorka doskonale się orientuje w problematyce tych lingwistycznych, a częściowo nawet wykraczających poza obszar klasycznego językoznawstwa, interdyscyplinarnych nurtów badawczych. Sprawnie operuje ich rozbudowaną siatką pojęciowo-terminologiczną. Trochę jedynie szkoda, że autorka explicite nie sformułowała teoretyczno-metodologicznych założeń swojej rozprawy (co by było pomocne jej czytelnikowi mniej zorientowanemu w problematyce nowych paradygmatów badawczych lingwistyki).

3. Budzące uznanie zaplecze erudycyjne pracy. Wykaz bibliografii (s. 323-339) obejmuje 15 słowników (zwykle wielotomowych), atlasów i encyklopedii, 5 zespołów archiwalnych i 320 opracowań (językoznawczych, historycznych i prawnych), z czego większość, gdyż 169 pozycji, to książki, nieraz wielotomowe. A należy tutaj podkreślić, że ten imponujący zestaw bibliograficzny bynajmniej nie ma na celu erudycyjnego popisu: gruntowna i krytyczna znajomość rozległej, w bardzo dużym stopniu interdyscyplinarnej literatury naukowej ma w rozprawie charakter wysoce „sfunkcjonalizowany” (umiejętnie przez autorkę wyzyskana, stanowi ona naukowe tło i kontekst rozprawy, która dzięki temu zyskuje na głębi i gruntowności).

4. Zakres zrelacjonowanych w pracy badań. Większość autorów dzisiejszych rozpraw z zakresu historycznej stylistyki, socjolingwistyki (w szerokim tego terminu znaczeniu, obejmującym, oprócz socjolektów stricto sensu, także profesjolekty) czy genologii lingwistycznej, jak o tym świadczy obserwowana w tym względzie praktyka, ograniczyłaby się do tego, co stanowi - w planie merytorycznym - pierwszą część recenzowanej pracy (formalnie jest to część druga (s. 41-125), gdyż pierwsza (s. 13-40) obejmuje wstępne informacje o tradycji notariatu jako instytucji prawnej, o aktach notarialnych i ich historycznej ewolucji, o dziejach polskiego języka prawnego i prawniczego, o badaniach z zakresu tzw. juryslingwistyki, wreszcie o historii ziemi łukowskiej), tzn. do charakterystyki łukowskich aktów notarialnych jako swoistego gatunku wypowiedzi. Ewentualnie, w najlepszym razie, niektórzy z tych autorów dołączyliby może ukierunkowaną stylistycznie i genologicznie charakterystykę ich słownictwa i frazeologii (ograniczoną oczywiście do elementów w tej perspektywie nacechowanych). Tymczasem Joanna Kuć zdecydowała się ponadto na szczegółową, wyczerpującą charakterystykę pisowni łukowskich aktów notarialnych (choć nie pokusiła się o sformułowanie hipotezy wyjaśniającej najosobliwszą i najbardziej odbiegającą od ówczesnej przeciętnej ortograficznej cechę pisowni łukowskich aktów notarialnych, a mianowicie wyraźną nadreprezentację grafemu z) i ich polszczyzny w płaszczyźnie systemowej - od fonetyki po składnię. Dzięki temu jej praca dodatkowo stanowi ważny i interesujący przyczynek do XIX-wiecznych dziejów polskiego języka literackiego, a przynajmniej jego regionalnego wariantu z pogranicza wschodniej Małopolski i Podlasia. 
5. Ważne i interesujące wyniki naukowe (jako skutek wyżej wskazanych zalet), zebrane przez autorkę we wnioskach wieńczących poszczególne partie rozprawy (s. 121-125, 144-145, 151-152, 175-177, 212-214, 249-251 i 311-314) i w jej Zakończeniu (s. 315-318). Spośród nich szczególną uwagę bym zwrócił na stwierdzenia: o koniecznej ostrożności przy sporządzaniu typologii XIX-wiecznych umów, motywowanej nie do końca konsekwentną nominacją jednostek notarialnych; o względnej typowości fonetyki badanych dokumentów dla języka doby nowopolskiej (co nie wyklucza pewnych przejawów regionalności - obecności cech mazowieckich i północnomałopolskich); ta sama względna reprezentatywność łukowskich aktów notarialnych dotyczy fleksji polszczyzny pierwszej połowy XIX wieku (wśród stosunkowo nielicznych archaizmów fleksyjnych autorka słusznie zwraca uwagę na imiesłowy typu majęcy); w składni na czoło się wysuwają konstrukcje właściwe stylowi urzędowemu z jego składnią znominalizowaną (unikającą orzeczenia wyrażonego czasownikiem), przy równoczesnej obecności nielicznych, lecz wyraźnych składniowych cech kresowych; w obszarze słowotwórstwa autorka zwraca uwagę na produktywność modeli charakterystycznych dla terminologii specjalistycznej (np. na tendencję do compositów czy na semantyczną repartycję jednostek wspólnofunkcyjnych); w obszarze wyselekcjonowanego słownictwa zwracają uwagę liczne zmiany semantyczne i/lub morfologiczne, a także wyrazy nieznane stosownym źródłom leksykograficznym (słownikom: Lindego i wileńskie$\mathrm{mu}$ ); materiał ten potwierdza też silny wpływ łaciny na polszczyznę w przeszłości, a także współczesne (badanym łukowskim aktom notarialnym) wpływy francuskie i niemieckie; w Zakończeniu autorka podkreśla to, że dalszych badań wymaga różnorodność genologiczna XIX-wiecznych tekstów prawnych oraz ich stosunek do tradycji prawnej i do dzisiejszego języka prawnego i prawniczego. Ostateczna, najogólniejsza konkluzja autorki brzmi:

„Łukowskie notariaty to dokumenty hieratyczne, w których dążenie do monolityczności wydatnie wyeksponowane licznymi odniesieniami w kompozycji i strukturze powoduje, że odbieramy je współcześnie jako silnie zakorzenione w kulturze i języku, trwałe gatunkowo i jednorodne teksty, które są prawdziwą skarbnicą wiedzy o polskim języku prawnym i prawniczym funkcjonującym w pierwszej połowie XIX wieku” (s. 318).

Wobec budzącej podziw obfitości materiału językowego, zwłaszcza w trzeciej części pracy, nie można się dziwić, że autorka nie ustrzegła się, zresztą nielicznych, drobnych usterek i uchybień. Czasem zresztą może tu chodzić o pewien skrót myślowy czy nieścisłość sformułowania, na przykład gdy autorka wśród przymiotników możliwościowych na -alny (typu mieszkalny) wymienia używalność (rzeczownik, ale strukturalnie zakładający istnienie przymiotnika używalny (s. 235) czy gdy o formancie -ity (całkowity, pracowity, przyzwoity itd.) twierdzi, że jest prasłowiański, a w polszczyźnie funkcjonuje od XIV wieku (s. 234): w istocie, jeśli coś jest prasłowiańskie i w polszczyźnie odziedziczone (a nie zapożyczone z innego języka słowiańskiego, bo taka możliwość też istnieje), to niezależnie od pierwszego świadectwa filologicznego (wiadomo, że polszczyzna przeżyła epokę przedpiśmienną) w języku polskim istniało od zawsze, tzn. od jego początku. Niemniej jednak należałoby sprostować tezę autorki o genezie denazalizacji tylnej samogłoski nosowej 
w Małopolsce pod wpływem polszczyzny kresowej (s. 147-148): czym innym jest kresowa denazalizacja tylnej samogłoski nosowej w wygłosie, a czym innym denazalizacja każdej (nie tylko wygłosowej) nosówki tylnej w Małopolsce północnej czy w pasie beskidzkim.

Niektóre przykłady (nieliczne wobec ich obfitości) są chyba mało wyraziste i na skutek tego niełatwe do interpretacji. Moim zdaniem na przykład nie wszystkie przykłady na s. 205 rzeczywiście ilustrują różne podmioty w zdaniach z równoważnikiem imiesłowowym, a na s. 206 nie wszystkie przykłady świadczą o samodzielności orzeczeniowej imiesłowów na $-a c$.

Zdarzają się - również bardzo rzadko na tle liczby analizowanych form - usterki $\mathrm{w}$ interpretacji słowotwórczej. Na przykład w czasowniku wydać nie ma przyrostka - $a-$, bo - $d a$ - tutaj to prastary, jeszcze praindoeuropejski pierwiastek $* d a-$. Relatywnie częściej myli autorka interpretację słowotwórczą z morfologiczną: mówi o formantach przedrostkowych tam, gdzie przedrostki w istocie stanowią część podstawy słowotwórczej. Na przykład (s. 239) dozwalać czy dostrzegać pochodzą od dozwolić i dostrzec, a nie od *zwalać czy *strzegać. Podobnie od formacji dokonanych pochodzą niedokonane z innymi przedrostkami, np. opłacać (s. 240), ustanawiać, ułatwiać, uspokajać, usprawiedliwiać się (s. 244), wytyczać (s. 245), zastrzegać, zaspokajać, zabezpieczać, załatwiać, zamykać, zatrudniać się (s. 246).

W części leksykalnej nieliczne drobne usterki dotyczą objaśnień etymologicznych. Na przykład na s. 268 autorka łacińskie ablatus objaśniła jako 'wycofane', a ablatus to przecież forma rodzaju męskiego. Francuskie deshabillée (s. 297), rodzaju żeńskiego, to etymologicznie 'rozebrana', a nie 'obnażony' (co zresztą, leksykalnie rzecz biorąc, na jedno wychodzi). Niektóre nieścisłości mają chyba źródło w możliwościach edytorskich wydawnictwa, na przykład (s. 269) greckie prōtón kōlon (ostatecznie źródło etymologiczne protokołu) zamiast poprawnego proton kólon. Jedyna usterka „realna” dotyczy etymologii korca (s. 292): sugestia autorki, że korzec jest zapożyczeniem ze słowackiego korec, nie znajduje żadnego potwierdzenia w źródłach leksykograficzno-etymologicznych. W języku polskim w ogóle nie ma starych pożyczek słowackich (inaczej się przedstawia, jak wiadomo, sprawa z czeskimi, czeskie kořec jest jednak najprawdopodobniej zwykłym odpowiednikiem koetymologicznym polskiego korca). Jednym słowem, wszystko wskazuje na to, że korzec jest wyrazem rodzimym o genealogii prasłowiańskiej.

Wyszczególnione wyżej drobne usterki w najmniejszym stopniu nie podważają bardzo wysokiej oceny książki Joanny Kuć. Ta znakomita, bardzo wartościowa rozprawa wejdzie niewątpliwie do trwałego dorobku językoznawstwa polskiego. 